\section{DiscoverSys \\ Published by DiscoverSys \\ Preparedness of general practitioners in providing health services to foreign tourists in Bali, Indonesia}

\author{
Anak Agung Sagung Sawitri,, Putu Cintya Denny Yuliyatni
}

CrossMark

\section{ABSTRACT}

Background and purpose: Bali was visited by more than 4.9 million foreign tourists in 2016. To some extent foreign tourists may need health services during their travel. This study aims to describe perception of preparedness of general practitioners (GPs) to provide health services for foreign tourists.

Methods: Surveys were conducted among foreign tourists who visited Bali in 2012 and among GPs in 2013. Self-administered questionnaires on the level of satisfaction were completed by 108 foreign tourists. Structured questionnaires exploring the travel medicine knowledge and English language proficiency were completed by 109 GPs. The experience of foreign patients was used to triangulate the response from GPs.

Result: Good satisfaction in terms of capacity of GPs to provide quality services reported by foreign tourists was varied between $76 \%$ and $85 \%$. Assessment of level of knowledge among GPs regarding travel medicine showed that 33\% GPs were having good knowledge, $55.1 \%$ fair and $11.9 \%$ poor. The proportion of correct answer of several items were low, which included recommended vaccine (11\%), management of jetlag $(13,8 \%)$, symptoms of barotrauma during diving $(13,8 \%)$, sunburn and protection $(31,2 \%)$, malaria prevention $(21 \%)$, and diarrhea management $(27,5 \%)$. Good satisfaction of English communication reported by foreign tourists was between $65 \%$ and $78 \%$. Meanwhile, $60 \%$ GPs believed to have good English communication with their foreign patients.

Conclusion: Preparedness of general practitioners to deliver health services and in English communication to foreign tourists was generally sufficient. Knowledge of GPs on several aspects of travel medicine was insufficient.
Department of Community and Preventive Medicine Faculty of Medicine Udayana University

*Correspondence to: Anak Agung Sagung Sawitri, Department of Community and Preventive Medicine Faculty of Medicine Udayana University cintyaputu@gmail.com

Keywords: Bali, preparedness, general practitioners, foreign tourist, health clinic Cite This Article: Sawitri, A.A.S., Yuliyatni, P.C.D. 2017. Preparedness of general practitioners in providing health services to foreign tourists in Bali, Indonesia. Public Health and Preventive Medicine Archive 5(1):54-60. D0I:10.15562/phpma.v5i1.44

\section{INTRODUCTION}

As one of the most popular foreign tourist destinations in the world, Bali was visited by more than 4.9 million people in 2016 , increased $23 \%$ compared to the 2015. ${ }^{1}$ Tourism industries are advancing to meet the growing demands and preferences of consumers. In addition to sight-seeing, foreign tourists enjoy activities with a risk of injury due to extreme sports such as bungy jumping, rafting, and parachute-sailing. It is also more common for foreign visitors to rent a motorcycle during their stay - without any prior road experience and often without appropriate safety equipment. These carry a serious risk of accident that can lead to severe disabilities or death. ${ }^{2}$ In addition, travelers to Bali may be exposed to tropical diseases such as Japanese Encephalitis, ${ }^{3}$ traveler's diarrhea, ${ }^{4}$ dengue $^{5}$ and rabies. ${ }^{6}$ Meanwhile, the number of health facilities targeting foreign tourists is increasing. General practitioners (GPs), clinics and hospitals are often being the first to provide health services among foreign tourists. However, their capacity is yet to be evaluated. We provide a preliminary evaluation of the health services provided in Bali from the perspective of the foreign tourist patients and of the GPs in two districts as main tourism destinations in Bali.

\section{METHODS}

Two surveys were conducted to obtain information on the experience of foreign patients when receiving health care and the competency of GPs in delivering services to foreign tourists. The first survey was conducted in 2012, aimed at exploring the level of satisfaction of foreign (non Indonesian citizens) tourists who visited tourism areas in Ubud and Badung regarding health services in Bali. A total of 108 foreign tourists who participated in the survey have previously accessed health services in Bali either public or private facilities. Our interviewers conviniently approached foreign tourists at the tourism areas of Kuta, Ubud, and Sanur and invited them to complete an anonymous self-administered questionnaire about their experiences of utilizing health services in Bali. Several criteria were used to select eligible samples that were an adult male/ female foreign tourist, had utilised health care services in Bali, and have agreed to participate in the survey. This perception was assessed using a modification of a standardised published instrument, including four out of five dimensions of health service quality that were reliability (sub-items: punctuality of GPs at the clinic working hours and reasonability of cost), responsiveness (sub-items: 
capability of GPs to explain the disease, preparedness to provide support either directly or via phone, responsiveness in addressing complaints), assurance (sub-items: competency and bedside manner when providing services, and proficiency in English communication) and empathy (sub-item: attention of provider care when providing services). A question on the overall satisfaction of the general practitioners was also asked. Perception for each item was scored as 1 =disappointed, $2=$ unsatisfied, $3=$ less satisfied, 4=satisfied, 5=very satisfied and NA=not applicable. Scores from each person were summed, and the mean was used as a cut-off to categorize the status of satisfaction perception into less satisfied (1-3) and satisfied (4-5). This category was used because no published study can be referred to. This questionnaire was a modification of the satisfaction questionnaire which usually used to measure the level of satisfaction among patients in hospitals or clinics. We modified the questionnaire from the Indonesian version, and tested the questionnaire to allow similar understanding from the Indonesian and the English versions. No other validity test was done to the questionnaire. This study also looked at the demographic characteristics, type of clinics they used and clinical conditions when they accessed the health services.

The second survey was conducted in 2013, aimed to understand the perception of GPs who work at health facilities which provide services to foreigners. A total of 109 GPs in 54 health services (24 private clinics, 23 public clinics, 5 private practices, 2 hospitals) participated in this study. The list of private and government clinics and hospitals were taken from Bali Provincial Health Office, which were stated providing health services to foreign tourists in Denpasar and Badung Districts. During the process of data collection, several private clinics on the lists were not available (have been closed), and there were new clinics found not available on the list. We took all clinics available in Denpasar and Badung Districts which provide health services to foreign tourists as samples. From each clinic, we interviewed two GPs who were on duty at the clinic. While for hospitals, we interviewed two GPs who were in charged at the emergency unit. A structured questionnaire was adopted and modified from the School of Royal Tropical Curriculum $^{7}$ including basic health assessment, health risk reduction strategy, disease management, and post travel consultation. These were asked using 30 questions with a total correct score of 51, related to assessment of information and vaccine of tourist before travelling (1-3), the most causal of tourist death (4), healthy flight (5-9), healthy diving (10-14), animal bite (17-18), sunburn management (15-16), earwax (19), infection of malaria, diarrhea,
HIV, and legionella (20-30). Each correct answer was scored $=1$ and summed to gain a total score of knowledge. These scores were divided by 51 and were categorized as good (total score $>70 \%$ ), fair (total score 60\%-70\%), and poor (total score $<60 \%$ ) knowledge. Communication skills were assessed by a self-administered questionnaire. GPs conducted a self-evaluation to mark their capacity and proficiency in general English and English communication (Table 2). These were scored from 1 (not good) to 4 (very good). This study also collected demographic data as well as data on the work characteristics of GPs. Data were analyzed descriptively and triangulation was done between the provider and consumer perspectives.

All respondents enrolled in this study have provided their consent. Study protocol of these studies has been approved by the Human Research Ethics Committee of Faculty of Medicine Udayana University and Sanglah General Hospital Denpasar.

\section{RESULTS}

Foreign tourist respondents were predominantly $20-59$ of age, $56 \%$ female, and $68.5 \%$ bachelor and postgraduate. Foreign tourists from Australia, Europe, and Asia were equal in numbers, and about one third had been to Bali for more than 6 times. The reasons for accessing health services were primarily due to diarrhea or vehicular/motor accident; and clinics or hospitals were their first choice for health care. The GP respondents were aged of 20-39 (83.5\%), with an equal proportion of female and male. Many of them worked in clinics and public health centers with varying lengths of working experience. These characteristics are presented in Table 1.

In terms of communication using English language, the proportion of foreign tourists who were satisfied with communication skills of health care providers was over two third. This finding was in accordance to GPs' perception about their ability to communicate in English with their foreign patients; that approximately $60 \%$ of GPs who were confident with their English communication skills (Table 2).

Table 3 shows that more than two third of foreign tourists were satisfied with all aspects of the service they received. The highest level of satisfaction was related to attention and competency of GPs. But, there are still small portion of less and dissatisfaction, particularly related to responsiveness (speed acting) and followed by punctuality to provide results of patients' conditions.

The result of each question of knowledge related to travel medicine is provided in Table 4 . The table indicates that there are several important 
Table 1 Characteristics of general practitioners and foreign tourists

\begin{tabular}{|c|c|c|c|c|c|}
\hline \multicolumn{3}{|c|}{ Foreign tourists } & \multicolumn{3}{|c|}{ General Practitioner } \\
\hline Variables & $\mathbf{n}$ & $\%$ & Variables & $\mathbf{n}$ & $\%$ \\
\hline Age (year) & & & Age (year) & & \\
\hline$\leq 19$ & 18 & 16.7 & $20-29$ & 51 & 46.8 \\
\hline $20-39$ & 45 & 41.7 & $30-39$ & 40 & 36.7 \\
\hline $40-59$ & 38 & 35.2 & $40-49$ & 16 & 14.7 \\
\hline$\geq 60$ & 7 & 6.4 & $50-59$ & 2 & 1.8 \\
\hline Sex & & & Sex & & \\
\hline Female & 61 & 56.5 & Female & 59 & 54.1 \\
\hline Male & 47 & 43.5 & Male & 50 & 45.9 \\
\hline Education level & & & Year of graduate & & \\
\hline Elementary - high school & 34 & 31.5 & 1990-1999 & 15 & 13.9 \\
\hline Bachelor-post-graduate & 74 & 68.5 & $2000-2005$ & 33 & 30.5 \\
\hline Type of health services visited & & & $2006-2010$ & 38 & 35.2 \\
\hline Clinic and hospital & 90 & 83.3 & $>2010$ & 22 & 20.4 \\
\hline Public health center & 2 & 1.9 & Workplace & & \\
\hline Private practice & 0 & 0 & Clinic/hospital & 55 & 50.5 \\
\hline On call & 9 & 8.3 & Public health center & 45 & 41.3 \\
\hline Frequency of visit to Bali & & & Private Practice & 7 & 6.4 \\
\hline $1-5$ & 76 & 70.4 & On call & 2 & 1.8 \\
\hline $6-10$ or more & 32 & 32.6 & Length of work (year) & & \\
\hline Origin & & & $\leq 1$ & 26 & 24.1 \\
\hline Asia (Malaysia, Japan, India, Korea) & 28 & 25.9 & $1-5$ & 46 & 42.6 \\
\hline United States & 7 & 6.5 & 6-10 or more & 36 & 33.3 \\
\hline Europe & 33 & 30.6 & Division of work & & \\
\hline Australia & 40 & 37.0 & Polyclinic & 92 & 84.4 \\
\hline Disease occupied & & & Emergency unit & 15 & 13.8 \\
\hline Diarrhea & 26 & 24.1 & Ward unit & 2 & 1.8 \\
\hline Injury and accident & 18 & 16.1 & & & \\
\hline Allergic reaction & 15 & 13.9 & & & \\
\hline Headache & 13 & 12.0 & & & \\
\hline Alcohol intoxication & 13 & 12.0 & & & \\
\hline Food borne intoxication & 5 & 4.6 & & & \\
\hline $\begin{array}{l}\text { Others (dengue infection, sunburn, } \\
\text { skin infection, and ear infection) }\end{array}$ & 18 & 16.7 & & & \\
\hline
\end{tabular}

items with a low proportion of correct answers. For example, only $11 \%$ of providers were aware of the recommended vaccines prior to visiting Indonesia. Awareness of malaria prevention strategies (bed-nets and repellants, and chemoprophylaxis if visiting Papua NG) was also poor, likewise awareness of treatment for vibrio cholera and diarrhea was very low. Table 4 also demonstrates that in other aspects the proportion of correct answers were generally high; over $70 \%$ for questions related to diving and snorkelling, and infectious conditions such as Avian Influenza and Dengue.

\section{DISCUSSION}

To our knowledge, this is the first study in Indonesia that evaluates capacities of health provider to provide health services to foreign tourists in one of the famous foreign tourist destinations in the world. Previous studies in Thailand explored reasons for seeking medical treatments abroad. ${ }^{8,9}$ Although our study design and scope were limited both in size and in sample selection and only pursue GPs, the study managed to cover most clinics that serve tourists in Denpasar and Badung, which are known as the 
Table 2 Perception of providers' capacity in English communication

\begin{tabular}{|c|c|c|c|c|c|}
\hline \multicolumn{3}{|c|}{ Foreign tourist's perception } & \multicolumn{3}{|c|}{ GPs' perception } \\
\hline Variables & Good satisfaction (n) & $\%$ & Variables & $\mathbf{n}$ & $\%$ \\
\hline Proficiency & 70 & 64.8 & General English & & \\
\hline \multirow[t]{9}{*}{ Capability to explain } & 84 & 77.8 & Excellent & 4 & 3.7 \\
\hline & & & Good & 60 & 55.0 \\
\hline & & & Fair & 43 & 39.4 \\
\hline & & & Not capable & 2 & 1.8 \\
\hline & & & English Communication & & \\
\hline & & & Excellent & 3 & 2.8 \\
\hline & & & Good & 60 & 55.0 \\
\hline & & & Fair & 44 & 40.4 \\
\hline & & & Not capable & 2 & 1.8 \\
\hline
\end{tabular}

Table 3 Perception of provider's competency in delivering services

\begin{tabular}{|c|c|c|c|c|c|}
\hline \multicolumn{3}{|c|}{ Foreign tourist 's perception } & \multicolumn{3}{|c|}{ General Practitioners' perception } \\
\hline Variables & Good satisfaction (n) & $\%$ & Variables & $\mathbf{n}$ & $\%$ \\
\hline Competency & 89 & 82.4 & Descriptive (knowledge) & & \\
\hline Punctuality to inform & 84 & 77.8 & Range (total) & $23-40(51)$ & \\
\hline Timeline & 86 & 79.6 & Mean (SD) & $34.01(2.9)$ & \\
\hline Responsibility & 86 & 79.6 & Level of knowledge & & \\
\hline Responsiveness & 80 & 74.1 & Good $(>70)$ & 36 & 33 \\
\hline \multirow[t]{2}{*}{ Attention } & 91 & 84.3 & Fair $(60-70)$ & 60 & 55.1 \\
\hline & & & Poor $(<60)$ & 13 & 11.9 \\
\hline
\end{tabular}

\section{Table 4 Details of GPs' knowledge}

\begin{tabular}{|c|c|c|c|}
\hline Questions & Correct answers (n) & (\%) & $95 \% \mathrm{Cl}$ \\
\hline \multicolumn{4}{|l|}{ Assessment of information for travelling abroad ${ }^{a}$} \\
\hline Parents' name ${ }^{\mathrm{b}}$ & 95 & 87.2 & $80.9-93.5$ \\
\hline Age of client ${ }^{c}$ & 101 & 92.7 & $87.8-97.6$ \\
\hline Origin $^{c}$ & 8 & 7.3 & $2.4-12.2$ \\
\hline Reason for travel ${ }^{\mathrm{b}}$ & 92 & 84.4 & $77.6-91.2$ \\
\hline Destination country and length of stay ${ }^{c}$ & 105 & 96.3 & $92.8-99.8$ \\
\hline Type of journey ${ }^{c}$ & 23 & 21.1 & $13.4-28.8$ \\
\hline Pregnancy ${ }^{\mathrm{c}}$ & 101 & 92.7 & $87.8-97.6$ \\
\hline History of chronic diseases ${ }^{c}$ & 106 & 97.2 & $94.1-100.3$ \\
\hline History of immunization $^{c}$ & 103 & 94.5 & $90.2-98.8$ \\
\hline Number of accompanied families ${ }^{b}$ & 90 & 82.6 & $75.5-89.7$ \\
\hline Competency for GP related to travel medicine & 80 & 73.4 & $65.1-81.7$ \\
\hline Recommended vaccines prior to visit Indonesia & 12 & 11 & $5.1-16.9$ \\
\hline Highest cause of mortality among travelers & 36 & 33 & $24.2-41.8$ \\
\hline Risk of long flight & 105 & 96.3 & $92.8-99.8$ \\
\hline Condition of not risk for flight & 66 & 60.6 & $51.4-69.8$ \\
\hline Risk of Acute Coronary Syndrome during flight & 98 & 89.9 & $84.2-95.6$ \\
\hline Advice for asthmatic patients during flight & 90 & 82.6 & $75.5-89.7$ \\
\hline Prevention and management of Jet Lag & 15 & 13.8 & $7.3-20.3$ \\
\hline
\end{tabular}


Table 4 Continue

\begin{tabular}{|c|c|c|c|}
\hline Questions & Correct answers (n) & $(\%)$ & $95 \% \mathrm{Cl}$ \\
\hline \multicolumn{4}{|l|}{ In condition of Snorkeling and Diving } \\
\hline The need for epilepsy and asthmatic medication ${ }^{\mathrm{b}}$ & 82 & 75.2 & $67.1-83.3$ \\
\hline Early signs of depth disorder & 105 & 96.3 & $92.8-99.8$ \\
\hline The use of dark suits & 95 & 87.2 & $80.9-93.5$ \\
\hline Risk of sea creatures attack & 72 & 66.1 & $57.2-75.0$ \\
\hline Possible health disorders & 92 & 84.4 & $77.6-91.2$ \\
\hline Examination before diving & 77 & 70.6 & $62.0-79.2$ \\
\hline Symptoms of barotrauma during diving & 15 & 13.8 & $7.3-20.3$ \\
\hline Arterial Gas Embolism vs. Decompression Sickness & 83 & 76.1 & $68.1-84.1$ \\
\hline Early management for stick sea creature injury & 83 & 76.1 & $68.1-84.1$ \\
\hline Principles of sunburn management & 63 & 57.8 & $48.5-67.1$ \\
\hline Sunburn management and sun protection & 34 & 31.2 & $22.5-39.9$ \\
\hline First action due to snake bite & 69 & 63.3 & $54.3-72.3$ \\
\hline Management of dog bite & 81 & 74.3 & $66.1-82.5$ \\
\hline Earwax blocking & 90 & 82.6 & $75.5-89.7$ \\
\hline \multicolumn{4}{|l|}{ Area of Endemic Malaria } \\
\hline India $^{c}$ & 49 & 45 & $35.7-54.3$ \\
\hline Australia $^{\mathrm{b}}$ & 108 & 99.1 & $97.3-100.9$ \\
\hline Afrika $^{c}$ & 84 & 77.1 & $69.2-85.0$ \\
\hline Papua New guinea $^{c}$ & 99 & 90.8 & $85.4-96.2$ \\
\hline $\mathrm{USA}^{\mathrm{b}}$ & 109 & 100 & 100 \\
\hline \multicolumn{4}{|l|}{ Prevention of malaria in Bali } \\
\hline Using bednet ${ }^{\mathrm{b}}$ & 23 & 21.1 & $13.4-28.8$ \\
\hline Repellent ${ }^{\mathrm{b}}$ & 28 & 25.7 & $17.5-33.9$ \\
\hline Avoid to go out at night ${ }^{\mathrm{b}}$ & 87 & 79.8 & $72.3-87.3$ \\
\hline Chemo-prophylaxis ${ }^{s}$ & 92 & 84.4 & $77.6-91.2$ \\
\hline Stand-by Emergency Treatment $(\text { SBET })^{c}$ & 101 & 92.7 & $87.8-97.6$ \\
\hline Chemo-prophylaxis of malaria to Papua & 28 & 25.7 & $17.5-33.9$ \\
\hline Antibiotic for Vibrio Cholera & 37 & 33.9 & $25.0-42.8$ \\
\hline Advice for diarrhea and Charcoal consumption & 30 & 27.5 & $19.1-35.9$ \\
\hline Extended of stay related to shortage of ARV & 87 & 79.8 & $72.3-87.3$ \\
\hline HIV positive and going hajj & 56 & 51.4 & $42.0-60.8$ \\
\hline Advise to reduce risk behavior for HIV infection & 85 & 78 & $70.2-85.8$ \\
\hline Symptoms of Legionella & 65 & 59.6 & $50.4-68.8$ \\
\hline Avian Flu & 87 & 79.8 & $72.3-87.3$ \\
\hline Indication of hospitalization for dengue infection & 84 & 77.1 & $69.2-85.0$ \\
\hline
\end{tabular}

${ }^{a}=$ this question have more than 1 option of right answer; ${ }^{b}=$ get 1 score if respondent did not choose this option; ${ }^{c}=$ get 1 score if respondent chose this option

most favour foreign tourist destination. Looking at from two sides, the consumers and the providers, the study had provided more clear and accurate on profile of competency of GPs in providing health services.

This study found that the three most common illness experienced by foreign tourists were diarrhea, injury and accidents, and allergic reaction. Diarrhea is very common among foreign tourists who visit developing country. Previous study indicated that the rate of traveler's diarrhea is as high as 20\%-90\% per each 2-week stay. ${ }^{10}$ In Bali, stomach syndrome including diarrhea commonly found among foreign traveller is known as Bali belly. ${ }^{11,12}$ In more recent publication by WHO, injury and accident are the most common causes of morbidity and mortality among travellers which is also consistent with this study. ${ }^{13}$ 
The study found that foreign tourists have high proportion of good satisfaction on the overall competency of GPs in Bali. This findings encountered the statement of the Bali provincial government that health services in Bali received a number of complaints from tourists. ${ }^{14}$ However, in small proportion, this study also found that foreign tourists were less satisfied to GPs in terms of their responsiveness, responsibility, timeline and punctuality to inform about their illness. The last aspect may related to English comunication between providers and patients. Our study revealed that communication in English was a barrier to provide quality services to non-Indonesian patients for $40 \%$ of the GPs. Further analysis showed that older GPs who had longer working experiences were having better knowledge on travel medicine than those who had limited working experience after their graduation. In addition, higher level of knowledge was found among GPs who work at the clinic, private practice, and on call than those who work at the public health center (puskesmas). However, in terms of English communication the above trend was reversed. The younger GPs or those who just recently graduated were more confident with their English capacity and proficiency. This data suggest that language is a crucial barrier for older GPs to provide clear information which may affect the success of transferring information to their patients, particularly in relation to complications or the management of the occupied illness. ${ }^{15}$

The Faculty of Medicine Udayana University as the oldest and the only public university in Bali has prioritized travel medicine as a key feature for graduate GPs from Udayana since 2011. Some actions have been implemented in the university settings, for example providing specific travel medicine course attached to the GP's curriculum, providing additional travel medicine course by inviting travel medicine specialists, and sending some lecturers abroad to learn more on travel medicine. However, our data showed that GPs who graduated after 2011 had limited knowledge about travel medicine than those who graduated before 2011. It can be explained that working experiences and an independent long life learning after graduation are key factors that affect their current capacity. Additional efforts to increase knowledge of GPs on travel medicine need to be done continuously, not only in the class or graduate settings but also at the workplace settings, particularly in some important issues such as recommended vaccines, prevention and management of jet lag, symptoms of barotrauma, sunburn management and protection, malaria prevention, and diarrhea management. These efforts are essential to prepare GPs to work in the travel medicine field especially to equip them with knowledge and skills that include updating information of geography, infection related to travel, medicine and vaccine, risk of non-infectious diseases including environment, prevention and management, and post-travelling assessment. ${ }^{16}$ Furthermore, they should also be equipped with information on emerging infectious diseases, antibiotics resistance, global climate, ecological concerns, and politics. ${ }^{7,17}$

Apart from language barrier, the fact that the majority of tourists are from developed countries with advanced health care services, they tend to expect similar standard of care while they were in Bali. Furthermore, our data showed that the costs of health service for foreign tourists are much higher than prices for local residents, which is also another contributing factor of lack of satisfaction. A high cost of health services leads to higher expectation on the quality of health care. ${ }^{15,18}$ In public hospitals in Bali, there is only one standard cost which applied for both foreign tourists and local residents, and this situation may not be applicable at the private clinics or hospitals. There is a need to provide regulations from both provincial and national governments on the standard costs for health services for tourists.

This study is not without limitation. Finding the standard for questionnaire about travel medicine was challenging.

\section{CONCLUSION}

Knowledge among general practitioners were generally moderate to high within the high level of satisfaction among foreign tourists. Languange was the most common barrier to an effective communication between GPs and foreign tourists.

\section{CONFLICT OF INTEREST}

The authors have no any conflict of interests.

\section{ACKNOWLEDGEMENT}

Foremost, I would like to express my sincere gratitude to all respondents for being patience and honest with their response. I would also like to acknowledge the Bali Provincial Health Office and Provincial Tourism for their support during the surveys.

\section{REFERENCES}

1. Bali Tourism Office. The number of foreign tourists arrival to Bali by month [Internet]. Bali; 2014. Available from: http://www.disparda. baliprov.go.id/en/Statistics2

2. Wedagama D. The Influence of Accident Related Factors on Road Fatalities Considering Bali Province in Indonesia as a Case Study. J East Asia Soc Transp Stud [Internet]. 2010;8:1905-17. Available from: http://www.easts.info/ publications/journal_proceedings/journal2010/pdf 
3. Buhl M, Lindquist L. Japanese Encephalitis in Travelers: Review of Cases and Seasonal Risk. Int Soc Travel Med [Internet]. 2009;16(3):217-9. Available from: https://www. ncbi.nlm.nih.gov/ pubmed/19538584

4. Wittlinger F, Stefen R, Watanabe H, Handsxuh H. Risk of cholera among Western and Japanese travelers. J Travel Med [Internet]. 1995;2(3):154-8. Available from: https:// www.ncbi.nlm.nih. gov/pubmed/9815376

5. Yoshikawa MJ, Kusriastuti R. Surge of dengue virus infection and chikungunya fever in Bali in 2010: the burden of mosquito-borne infectious diseases in a tourist destination. Trop Med Heal [Internet]. 2013;41:67-78. Available from: https://www.ncbi.nlm.nih.gov/pmc/articles/ PMC3705185/pdf/tmh-41-67.pdf

6. FAO. Bali Serves as a Model for Control of Rabies [Internet]. 2012. Available from: http://www. fao.org/in-action/ bali-serves-as-a-model-for-control-of-rabies/en/

7. Royal College of Nursing London. Competencies: An Integrated Career and Competency Framework for Nurses in Travel Health Medicine [Internet]. Jane Chiodini, Lorna Boyne, Sandra Grieve, Alexandra Jordan, editors. London: the Royal College of Nursing ; 2007. 1-28 p. Available from: http://www.wales.nhs.uk/sitesplus/ documents/ 861/

8. Cohen E. Medical Tourism in Thailand. gsbejournal [Internet]. :25-37. Available from: http://www.graduate. au.edu/gsbejournal/

9. Ricafort KMF. A study of influencing factors that lead medical tourists to choose Thailand hospitals as medical tourism destination [Internet]. Wbster University; 2011. Available from: http://docplayer.net/4446685-A-study-ofinfluencing-factors-that-lead-medical-tourists-to-choosethailand-hospitals-as-medical-tourism-destination.html

10. Steffen R. Epidemiology of Traveler's Diarrhea. Oxford Journals Med Clin Infect Dis [Internet]. 2005;41(s8):S536-40. Available from: http:// cid.oxfordjournals.org/content/41/

11. Priherdityo E. Waspada serangan Bali belly saat liburan di Pulau Dewata. CNN Indonesia [Internet]. Jakarta; 2017;0. Available from: https://www.cnnindonesia.com/gayahidup/ 20161231163918-255-183364/waspada-seranganbali-belly-saat-liburan-di-pulau-dewata/
12. BIMC. Bali Belly [Internet]. Website. 2017 [cited 2017 Jul 23]. Available from: http:// bimcbali.com/medical-news/ bali-belly.html

13. WHO. International travel and health. Geneva: WHO; 2012. 1-274 p.

14. Popbali. Keluhan Wisatawan dan Keluhan Warga di Bali (Complaints of travellers and complaints of resident in Bali). Denpasar; 2014 Nov 27; Available from: http:// popbali.com/masalah kronis di Bali

15. Hill D, Ericsson C, Pearson R, Keystone J, Freedman D, Kozarsky P, et al. The Practice of Travel Medicine: Guidelines by the Infectious Diseases Society of America. Clin Infect Dis [Internet]. Philadelphia; 2006;1499-539. Available from: http://www.idsociety.org/ uploadedFiles/ IDSA/Guidelines-Patient_Care/PDF_Library/ TravelMedicine.pdf

16. Hill D, Rosselot G. Starting, Organization and marketing a Travel Clinic in Travel Medicine second edition. Travel Medicine. Elsevier Ltd. Philadelphia.; 2009. p. 13-27.

17. Levina P. Pelayanan Kedokteran Wisata Suatu Peluang: Cermin Dunia Kedokteran (Travel Health Services an Opportunity: Reflection of Medicine World). Jakarta; 2006;(152):6-8.

18. Hill D, Rosselot G. The Practice of Travel Medicine: Guidelines by the Infectious Diseases Society of America in IDSA [Internet]. 2011. Available from: cid. oxfordjournals.org

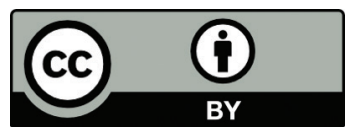

This work is licensed under a Creative Commons Attribution 